\title{
Design of Experimental Design as a Tool for the Processing and Characterization of HDPE Composites with Sponge-Gourds (Luffa-Cylindrica) Agrofiber Residue
}

\author{
Ana Maria F. Sousa ${ }^{1}$, Viviane A. Escócio ${ }^{1}$, Elen B. A. V. Pacheco ${ }^{1}$, Leila L. Y. Visconte ${ }^{1}$, André P. Cavalcante ${ }^{1}$, \\ Antonio G. Soares ${ }^{2}$, Murillo F. Junior ${ }^{2}$, Luiz C. C. Motta ${ }^{3}$ \& Gil F. C. Brito ${ }^{3}$ \\ ${ }^{1}$ Universidade Federal do Rio de Janeiro-Instituto de Macromoléculas Professora Eloisa Mano, Rio de Janeiro, \\ Brasil \\ ${ }^{2}$ Embrapa Agroindústria de Alimentos, Rio de Janeiro, Brasil \\ ${ }^{3}$ Instituto Nacional de Tecnologia, Rio de Janeiro, Brasil \\ Correspondence: Elen B. A. V. Pacheco, Universidade Federal do Rio de Janeiro-Instituto de Macromoléculas \\ Professora Eloisa Mano, Avenida Horácio Macedo, 2030, Prédio do Bloco J-CT, Cidade Universitária, Ilha do \\ Fundão, CEP 21941-598 Rio de Janeiro, Brasil. E-mail: elen@ima.ufrj.br
}

Received: February 20, 2013 Accepted: March 15, 2013 Online Published: March 28, 2013

doi:10.5539/jsd.v6n4p106

URL: http://dx.doi.org/10.5539/jsd.v6n4p106

\begin{abstract}
Sponge-gourd (Luffa-Cylindrica) agrofiber residue (LC)-HDPE composites were manufactured by extrusion and injection moulding. The effects of fiber content, fiber size, screw speed and barrel zones temperatures on tensile strength at yield (TS) point, modulus of elasticity (MOE), flexure stress (FS) and Izod pendulum impact resistance were evaluated by using a design of experiments (DOE)- $2^{4}$ Factorial with centerpoint. Furthermore, a model was also determined for each response variable as well as to generate foreknowledge for additional combinations of the experimental factors.

The design analysis showed that the LC-fiber content is the most important experimental factor, since it significantly affected three out of the four mechanical properties studied, specifically MOE, FS and Izod Impact resistance. The second most important parameter is the LC-fiber size. Additionally, the design analysis showed that screw speed and temperature of barrel zones did not present any influence on the properties investigated.

Finally, the models were validated by comparing the results from additional experimental runs with the predicted values obtained from the respective model.
\end{abstract}

Keywords: agrofiber residue, sponge-gourds, hdpe, composites, experimental design

\section{Introduction}

Nowadays, a great number of polymer science publications have been directed towards the development of new materials from renewable resources. In fact, natural fibers obtained from agro-industrial residues, such as jute, banana, henequen, coir, palm, bamboo, sisal, pineapple, wood, etc., used as substitutes for synthetic fibers have received considerable attention since they can be used to produce composites, which show good technical properties, economic benefits and present the sustainability criteria for development in the third millennium (Mishra et al., 2004; Finkler et al., 2005; Herrera-Franco \& Valadez-Gonzales, 2005; Lei et al., 2007; Mulinari et al., 2009; Liu et al., 2009).

Luffa cylindrica (Figure 1 and Figure 2) belongs to Cucurbitaceae family and is produced abundantly in many countries in the tropical and subtropical zones. It is a natural material with microcellular architecture and contains cellulose and lignin. Its main use is in bathing and washing applications. It is a natural material with microcellular architecture, contains cellulose and lignin and is produced abundantly in many countries in the tropical and subtropical zones. Although only few studies about Luffa sponge are available in technical literature (Altınısik et al., 2010; Boynard et al., 2003; Demir et al., 2006), they report the high potential of this material in such uses as carriers in bioreactors, scaffolds for tissue engineering and for the development of biofiber-reinforced composites (Altınısik, 2010; Boynard, 2003; Demir, 2006). 


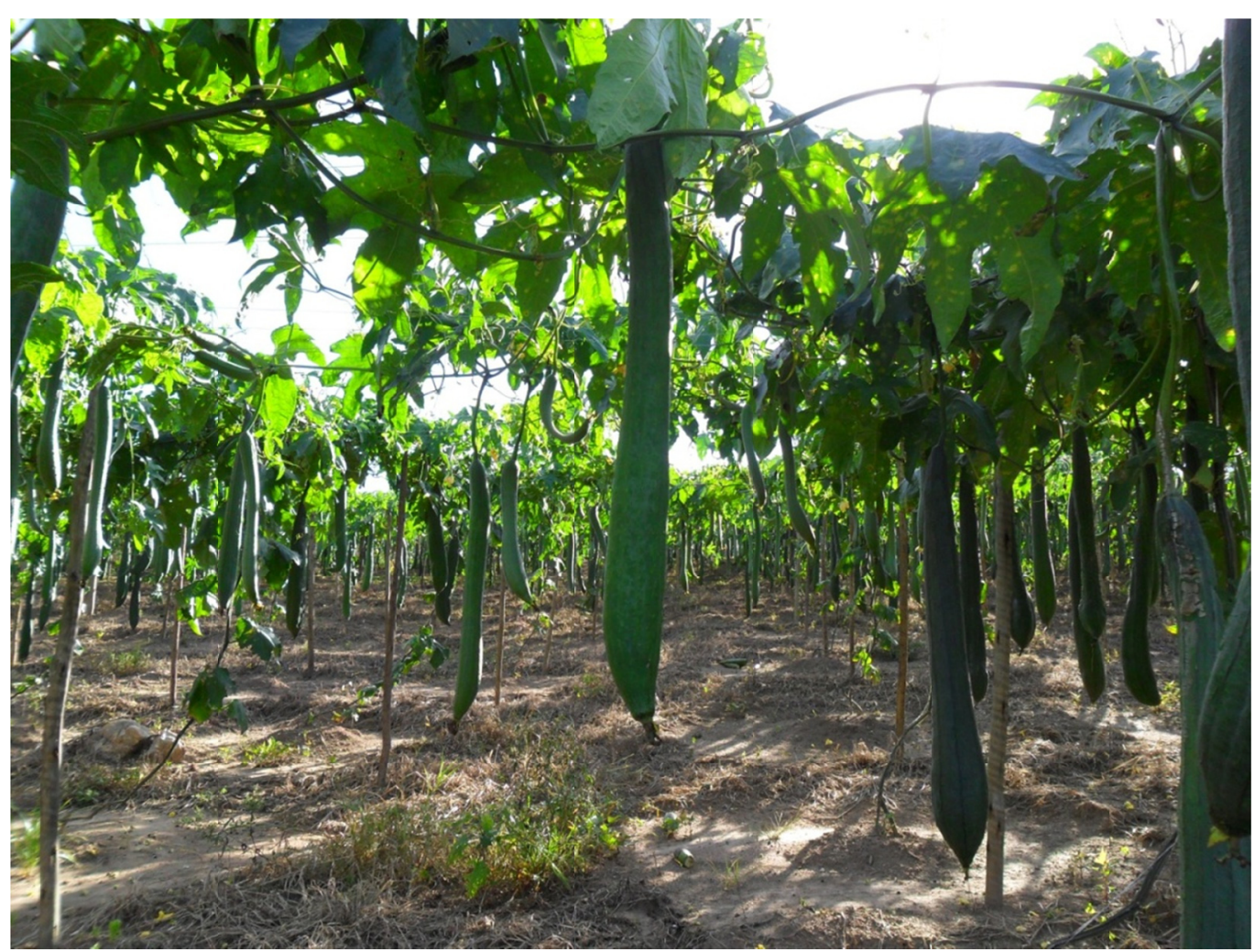

Figure 1. Luffa-Cylindrica plantation localized in Bonfim (Brazil)-(Picture by Viviane Escócio, 2011)

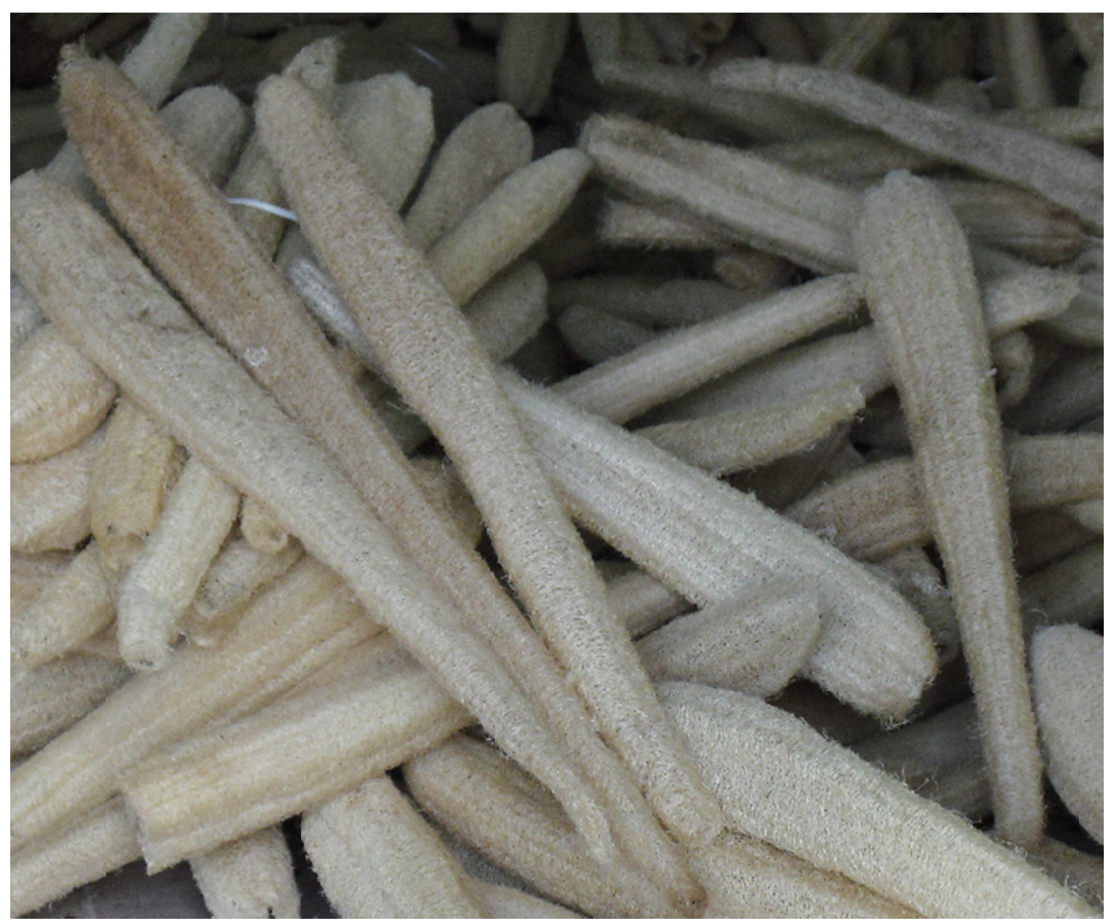

Figure 2. Luffa-Cylindrica (Picture by Viviane Escócio, 2011)

The town of Bonfim (in the State of Minas Gerais) is the most important producer of Luffa sponge in Brazil. This fruit is principally used to produce bath or kitchen sponges, however this process generates high amount of residue with no commercial application. Thus, the development of new applications for this Luffa Cylindrica residue could be an additional contribution to stimulate the growth of the local industry. This paper aims to 
evaluate the suitability of using sponge-gourds from agricultural residue to use in polymer composites based on lignocellulosic material.

This paper aimed to prepare HDPE-lignocellulosic composites by extrusion and injection moulding, analysing them by design of experimental tool. An experimental design was used in order to verify the influence and/or synergism among four experimental factors, namely fiber content, fiber size, screw speed and barrel zones temperatures, on the following response variables: tensile, flexural and Izod impact properties.

\section{Methods}

\subsection{Materials}

The high density polyethylene (HDPE) used was HD7255LS-L supplied by Braskem, Brazil. This material has density of $0.954 \mathrm{~g} / \mathrm{cm}^{3}$ and melt flow index (ASTM-D1238-10) of $4.5 \mathrm{~g} / 10 \mathrm{~min}\left(2.16 \mathrm{~kg}, 190{ }^{\circ} \mathrm{C}\right.$ ).

Sponge-gourds (Luffa-Cylindrica) agro-fiber residues were from the town of Bonfim (Minas Gerais). The sponge-gourds residue were characterized by moisture (ASTM D1348-94), density (ISO 8962), water extractive (TAPPI T212) and ash content (TAPPI T211), and through thermogravimetric analysis (TA-Q500 thermal gravimetric analyzer-TA Instruments) under nitrogen atmosphere at a heating rate of $20^{\circ} \mathrm{C} / \mathrm{min}$.

Prior to be used, the agrofiber residue was cleaned in order to have seeds and impurities removed. Then, the material was chopped by passing it through a mill and sieved so as to produce three fractions of fibers (20-40\#, 40-70\# and 70-100\#). All fractions were dried at $60^{\circ} \mathrm{C}$ for 24 hour in an air-circulating oven before being used.

\subsection{Composites Preparation and Design of Experiments}

Composites of Luffa-Cylindrica lignocellulosic fibers (LC-fiber) and HDPE were produced by extrusion using design of experiments (DOE)-24 Factorial with centerpoint. Four experimental factors were studied, i.e., LC-fiber content, LC-fiber size, screw speed and barrel zone temperature. To simplify the descriptions, from now on the experimental factors will be referred to as:

- LC-fiber content: 'A'

- LC-fiber size: 'B'

- $\quad$ Screw speed: 'C'

- Barrel temperature zone: 'D'

Table 1. Design Matrix for Design of Experiments (DOE) $-2^{4}$ Factorial with centerpoint

\begin{tabular}{|c|c|c|c|c|}
\hline \multirow{2}{*}{ Experiments } & \multicolumn{4}{|c|}{ Experimental Factors } \\
\hline & A & B & C & D \\
\hline 1 & -1 & 1 & -1 & -1 \\
\hline 2 & 1 & 1 & -1 & -1 \\
\hline 3 & -1 & -1 & -1 & -1 \\
\hline 4 & 1 & -1 & -1 & -1 \\
\hline 5 & -1 & 1 & 1 & -1 \\
\hline 6 & 1 & 1 & 1 & -1 \\
\hline 7 & -1 & -1 & 1 & -1 \\
\hline 8 & 1 & -1 & 1 & -1 \\
\hline 9 & -1 & 1 & -1 & 1 \\
\hline 10 & 1 & 1 & -1 & 1 \\
\hline 11 & -1 & -1 & -1 & 1 \\
\hline 12 & 1 & -1 & -1 & 1 \\
\hline 13 & -1 & 1 & 1 & 1 \\
\hline 14 & 1 & 1 & 1 & 1 \\
\hline 15 & -1 & -1 & 1 & 1 \\
\hline 16 & 1 & -1 & 1 & 1 \\
\hline $17-1$ & 0 & 0 & 0 & 0 \\
\hline $17-2$ & 0 & 0 & 0 & 0 \\
\hline $17-3$ & 0 & 0 & 0 & 0 \\
\hline $17-4$ & 0 & 0 & 0 & 0 \\
\hline $17-5$ & 0 & 0 & 0 & 0 \\
\hline
\end{tabular}


Tables 1 and 2 show the experimental factors with their normalized levels and the design matrix of $2^{4}$ Factorial with centerpoint, respectively.

Table 2. Experimental Factors and Levels Used

\begin{tabular}{cccc}
\hline \multirow{2}{*}{ Factor } & Low level & Centerpoint & High level \\
\cline { 2 - 4 } & $(-1)$ & 0 & $(+1)$ \\
\hline $\mathrm{A}$ & $10 \%$ & $20 \%$ & $30 \%$ \\
\hline \multirow{2}{*}{$\mathrm{B}$} & $0.63 \mathrm{~mm}$ & $0.39 \mathrm{~mm}$ & $0.15 \mathrm{~mm}$ \\
& $(20-40 \mathrm{mesh})$ & $(40-70 \mathrm{mesh})$ & $(70-100 \mathrm{mesh})$ \\
\hline $\mathrm{C}$ & $300 \mathrm{RPM}$ & $375 \mathrm{RPM}$ & $450 \mathrm{RPM}$ \\
\hline \multirow{2}{*}{$\mathrm{D}$} & Zone $2-5: 140{ }^{\circ} \mathrm{C}$ & Zone $2-5: 160{ }^{\circ} \mathrm{C}$ & Zone $2-5: 180{ }^{\circ} \mathrm{C}$ \\
& Zone 6-9: $160^{\circ} \mathrm{C}$ & Zone 6-9: $180^{\circ} \mathrm{C}$ & Zone 6-9: $200{ }^{\circ} \mathrm{C}$ \\
& Die: $180{ }^{\circ} \mathrm{C}$ & Die: $200{ }^{\circ} \mathrm{C}$ & Die: $220{ }^{\circ} \mathrm{C}$ \\
\hline
\end{tabular}

Extrusion was carried out in a Tecktril co-rotating twin-screw extruder, model DCT-20, with length to diameter ratio $(\mathrm{L} / \mathrm{D})=36$ and feeding zone temperature of $90{ }^{\circ} \mathrm{C}$. Feeding was performed by using a volumetric feeder with speed of 15RPM, delivering $107 \mathrm{~g}$ of material per min. The extrudated material were quenched in a cold water bath, grinded into pellets and dried in an air- circulating oven during 24 hour at $60^{\circ} \mathrm{C}$.

Standard test specimens were injection molded on an Injection Molding Machine (Allrounder 270S-400-170, Arbourg, Germany) with effective screw length (L/D) of 20. The injection parameters were set at: zone temperatures of $160,175,185,195$ and $205{ }^{\circ} \mathrm{C}$ from feeding to nozzle, feed rate of $26 \mathrm{~cm}^{3} / \mathrm{s}$ and injection pressure of $1400 \mathrm{bar}$.

\subsection{Mechanical Properties}

The specimens were conditioned in laboratory for a period of 48 hours, at $25{ }^{\circ} \mathrm{C}$ and $50 \%$ of relative humidity.

Tensile and flexural tests were performed according to ASTM D638-03 and ASTM D790-03 standards, respectively, using an EMIC testing machine, Model DL3000, with 10kN load cell. The composites results were averaged over six measurements. The tensile strength at yield (TS) and modulus of elasticity (MOE) were measured using type I specimens and cross-head speed of $10 \mathrm{~mm} / \mathrm{min}$. Flexure stress (FS) (three point bending) was measured using span of $520 \mathrm{~mm}$ and cross-head speed of $19 \mathrm{~mm} / \mathrm{min}$.

Izod pendulum impact resistance was performed using a CEAST Resil Impactor tester, according to ASTM D256-06a standard. The composites results were averaged over eight measurements.

\subsection{Experimental Analysis}

Analysis of variance (ANOVA) was used to investigate how the experimental factors and their interactions affect a few mechanical properties of LC-fiber/HDPE composites. In this work, " $p$ value" lower than 0.05 indicates that the specific experimental factor and/or its interactions have significant influence on the response variable. However, instead of presenting ANOVA tables, standardized Pareto charts will be shown since the method allows the significant factors and interactions to be easily visualized (a line is drawn on the Pareto chart beyond which an factor/interaction is statistically significant, using 5\% significance level). In addition to Pareto ANOVA analysis, it was also determined for each response variable a statistical second-order model so as to allow predictions for additional combinations of the experimental factors. All analyzes were performed using the software Statgraphics Centurion XV version 15.2.06.

\section{Results and Discussion}

In order to characterize Luffa-Cylindrica agrofiber residue, seven samples were randomly taken from the batch received from Bonfim. The mean intervals of all properties tested in this study is shown in Table 3. 
Table 3. Properties of sponge-gourds waste ( $95 \%$ confidence intervals for mean)

\begin{tabular}{lc}
\hline Property & Mean \\
\hline Moisture, $\%$ & $10.1-11.3$ \\
\hline Density, $\mathrm{g} / \mathrm{cm}^{3}$ & $1.2-1.3$ \\
\hline Ash, $\%$ & $0.3-0.7$ \\
\hline Water Extractive, $\%\left(70^{\circ} \mathrm{C}\right)$ & $1.5-4.0$ \\
\hline Maximum degradation temperature, ${ }^{\circ} \mathrm{C}$ & $352-372$ \\
\hline
\end{tabular}

The test results of LC-fiber/HDPE composites carried out according to DOE- $2^{4}$ Factorial with centerpoint are shown in Table 4.

Table 4. Mechanical properties of LC-fiber/HDPE composites

\begin{tabular}{|c|c|c|c|c|c|}
\hline \multicolumn{2}{|c|}{ Experiments } & $\begin{array}{c}\mathrm{RT} \\
(\mathrm{MPa})\end{array}$ & $\begin{array}{c}\mathrm{ME} \\
(\mathrm{MPa})\end{array}$ & $\begin{array}{c}\mathrm{RF} \\
(\mathrm{MPa})\end{array}$ & $\begin{array}{c}\text { RI Izod } \\
(\mathrm{J} / \mathrm{m})\end{array}$ \\
\hline \multicolumn{2}{|c|}{1} & 17,89 & 809 & 29,7 & 57,00 \\
\hline \multicolumn{2}{|c|}{2} & 17,29 & 1410 & 34,8 & 53,46 \\
\hline \multicolumn{2}{|c|}{3} & 17,91 & 821 & 28,8 & 63,09 \\
\hline \multicolumn{2}{|c|}{4} & 17,83 & 1331 & 34,5 & 52,87 \\
\hline \multicolumn{2}{|c|}{5} & 17,85 & 836 & 29,9 & 59,10 \\
\hline \multicolumn{2}{|c|}{6} & 17,40 & 1439 & 34,2 & 52,00 \\
\hline \multicolumn{2}{|c|}{7} & 17,72 & 820 & 28,8 & 73,03 \\
\hline \multicolumn{2}{|c|}{8} & 17,99 & 1421 & 34,2 & 59,67 \\
\hline \multicolumn{2}{|c|}{9} & 17,81 & 839 & 29,7 & 63,05 \\
\hline \multicolumn{2}{|c|}{10} & 16,94 & 1496 & 34,2 & 46,97 \\
\hline \multicolumn{2}{|c|}{11} & 14,22 & 510 & 28,7 & 92,78 \\
\hline \multicolumn{2}{|c|}{12} & 18,10 & 1474 & 34,9 & 64,77 \\
\hline \multicolumn{2}{|c|}{13} & 17,78 & 755 & 29,8 & 59,34 \\
\hline \multicolumn{2}{|c|}{14} & 17,64 & 1369 & 33,7 & 56,77 \\
\hline \multicolumn{2}{|c|}{15} & 17,54 & 802 & 28,5 & 75,31 \\
\hline \multicolumn{2}{|c|}{16} & 18,26 & 1489 & 34,7 & 65,92 \\
\hline $17-1$ & \multirow{5}{*}{ 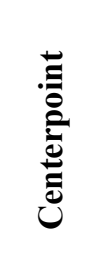 } & 17,71 & 1079 & 32,1 & 71,73 \\
\hline $17-2$ & & 17,30 & 1091 & 31,0 & 71,60 \\
\hline $17-3$ & & 17,21 & 1111 & 32,3 & 69,56 \\
\hline $17-4$ & & 17,82 & 1125 & 32,5 & 74,96 \\
\hline $17-5$ & & 18,00 & 1085 & 31,3 & 81,51 \\
\hline
\end{tabular}

The standardized Pareto charts for tensile strength at yield (TS) is presented in Figure 3. Regarding this property, no significant differences among experimental values were found and no experimental factor had any effect on the property. As indicated in Figure 3 and confirmed in Figure 4, only an AB synergism is detected, specifically, a slight improvement of TS by increasing LC-fiber content, when the LC-fiber size level is -1 (\#20-40mesh). This result can be considered of interest since in general, the tensile stress of composites with untreated natural fibers decreases as the fiber content increases (Boynard et al., 2003). 


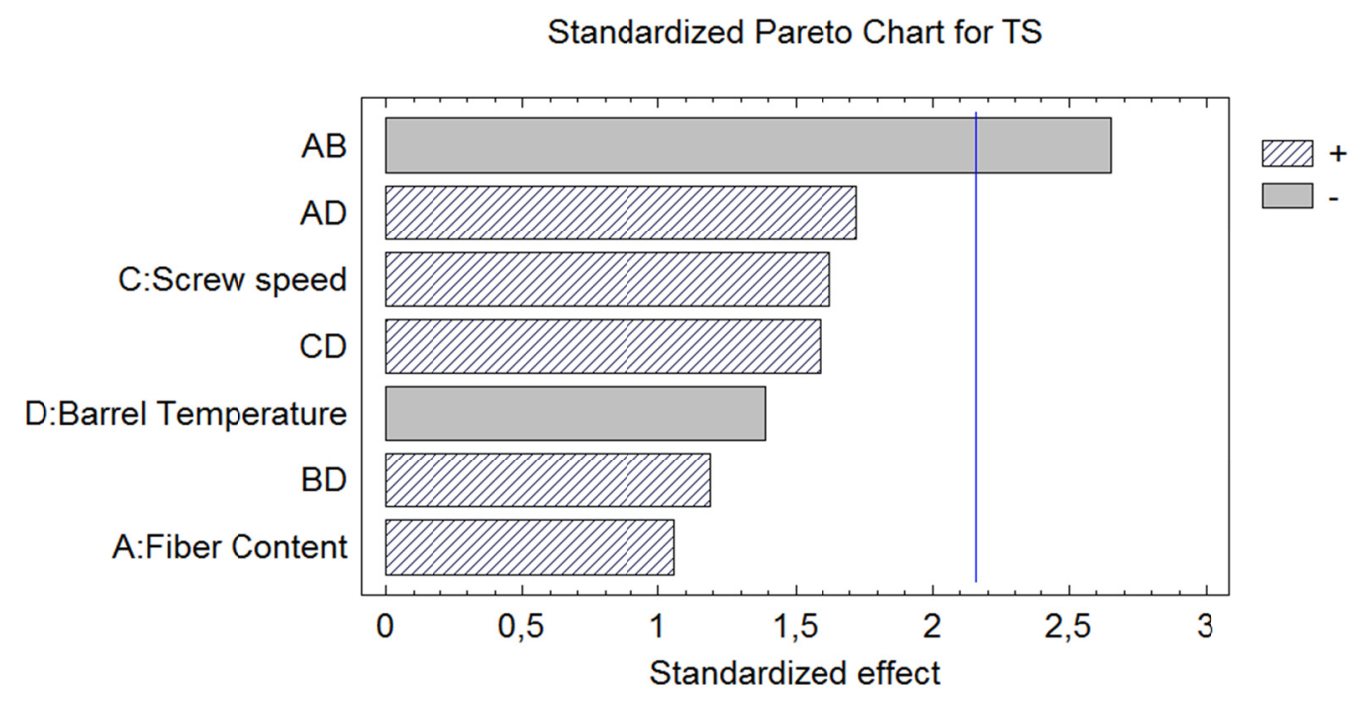

Figure 3. Standardized pareto chart for TS

Interaction Plot for TS

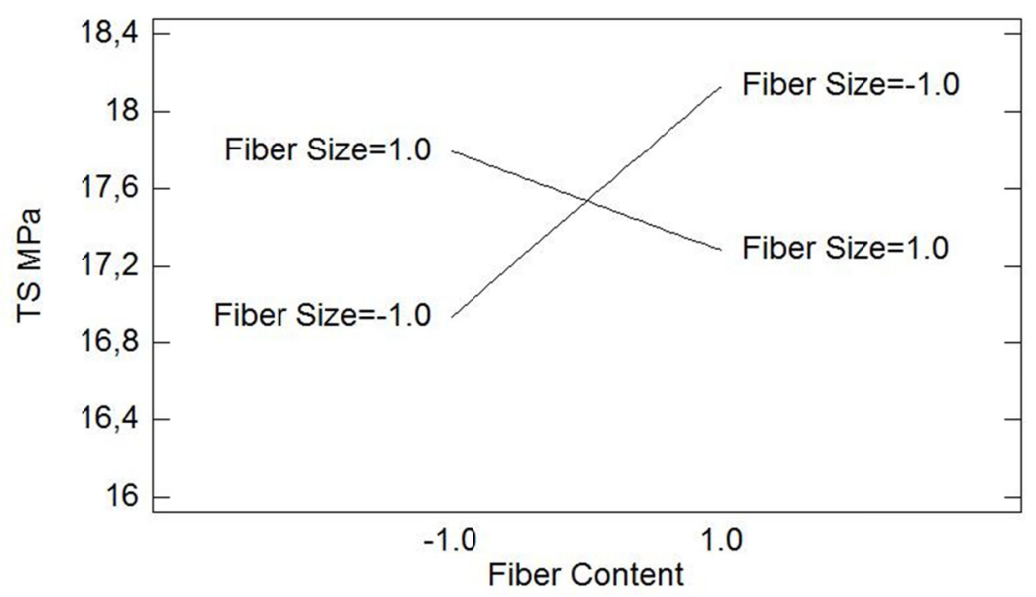

Figure 4. Tensile strength at yield (TS)-Interactions effects

As for MOE and FS, as shown at standardized Pareto charts in Figures 5 and 6, LC-fiber content is the unique experimental factor which has influence on those properties. As demonstrated in Figures 7 and 8, when the LC-fiber content is increased, MOE and FS also increase. These results can be of interest in the development of materials for construction and automotive industries. 
Standardized Pareto Chart for MOE

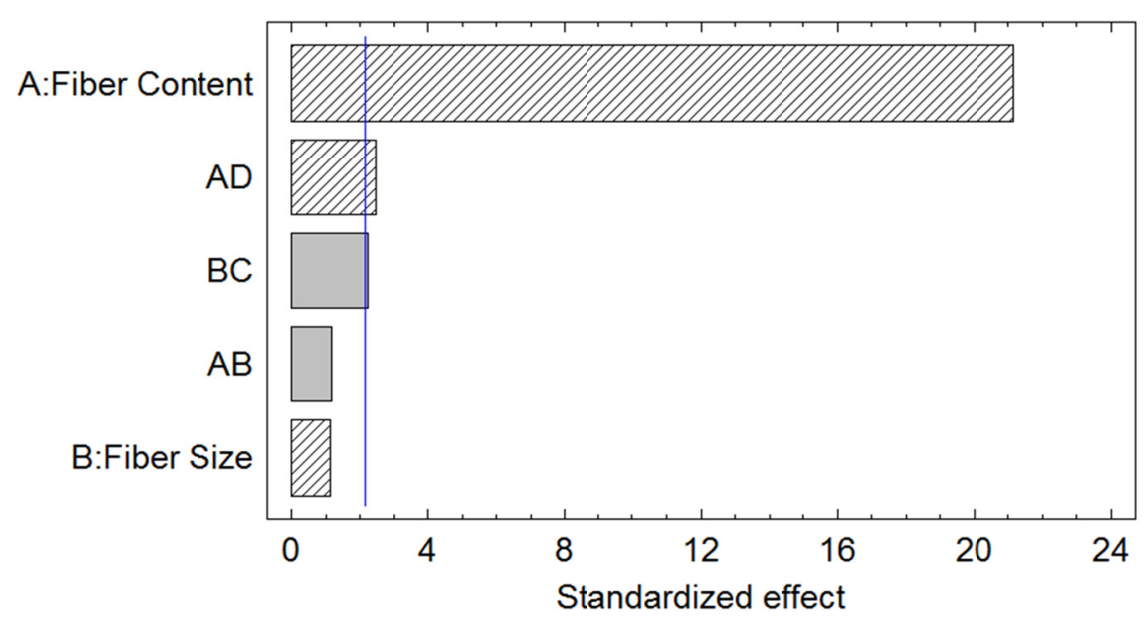

VIA +

$\square$ -

Figure 5. Standardized Pareto Chart for MOE

\section{Standardized Pareto Chart for FS}

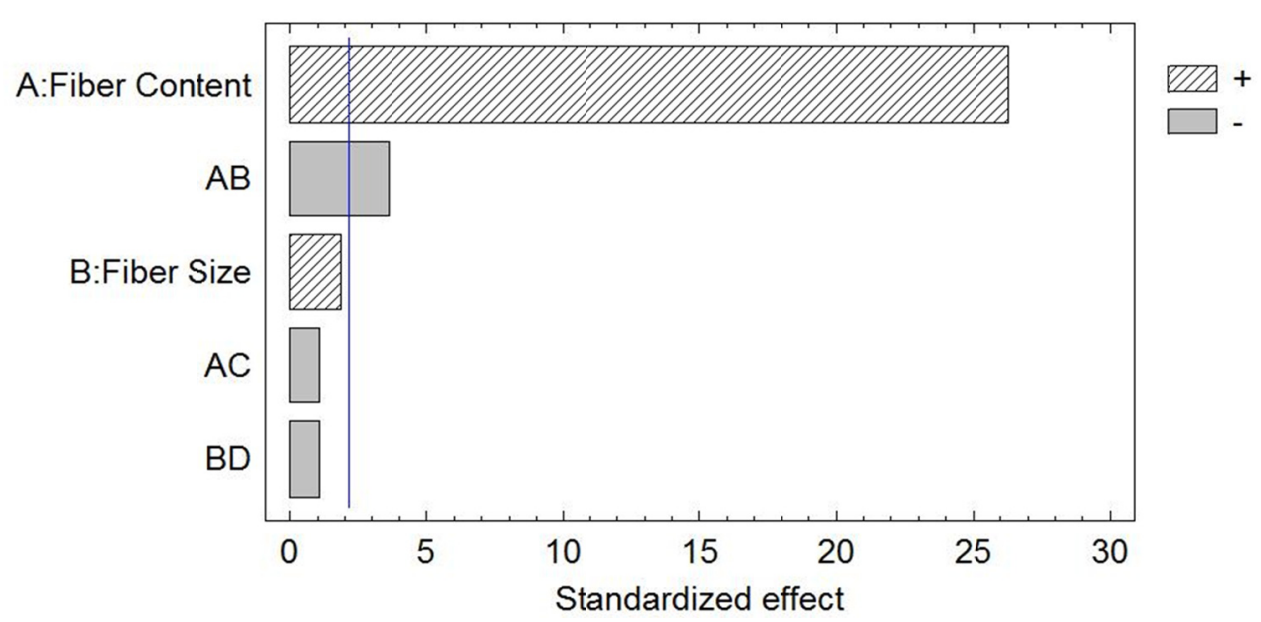

Figure 6. Standardized Pareto Chart for FS

Main Effects Plot for MOE

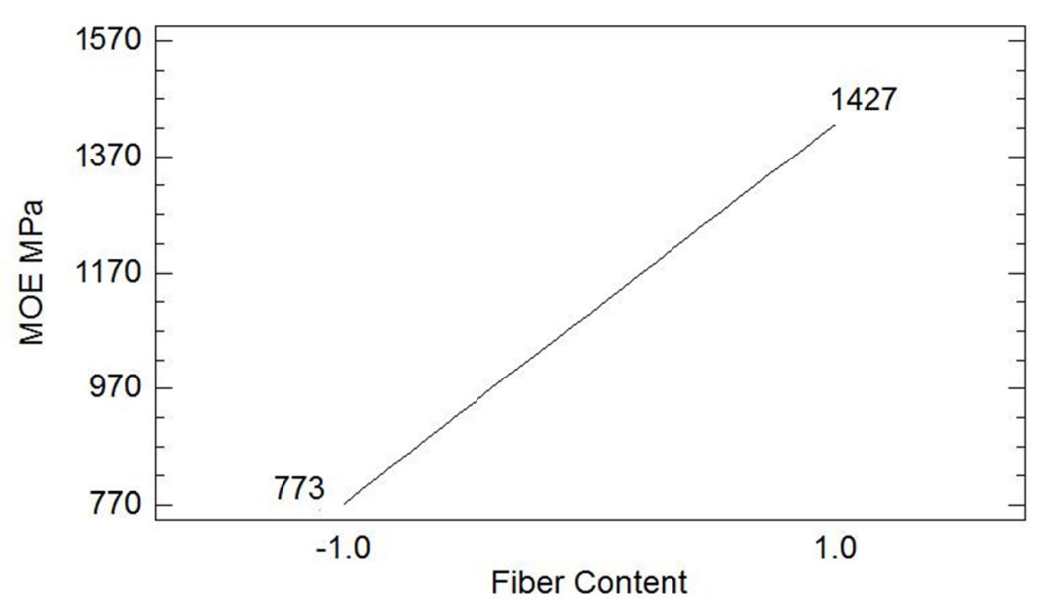

Figure 7. Modulus of elasticity (MOE) - Main effect 


\section{Main Effects Plot for FS}

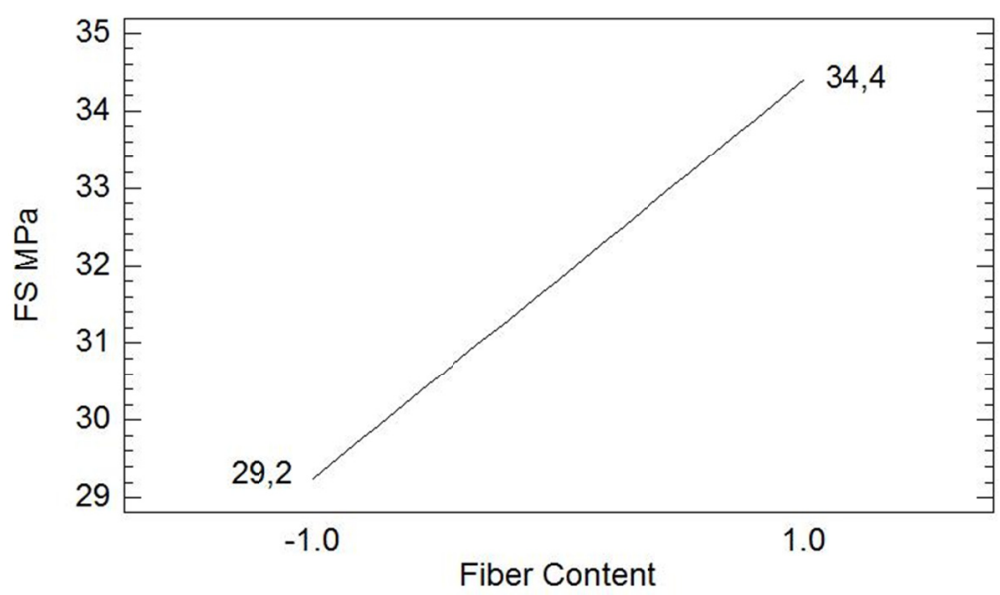

Figure 8. Flexure stress (FS)-Main effect

The statistical analysis for Izod impact resistance showed that this property was affected by both content and length of the fiber, as seen in Figures 9 and 10. Differently to the improvements found in MOE and FS properties by increasing the fiber content, the Izod impact resistance decreased. This result indicates that on adding higher contents of the lignocellulosic material the composite became more brittle. The decrease in impact resistance may have occurred due to fiber agglomeration and/or a weak interfacial adhesion between the hydrophilic fiber and the hydrophobic HDPE matrix, thus creating regions of stress concentration which require less energy to initiate or propagate a crack (Demir et al., 2006; Mohanty \& Nayak, 2010).

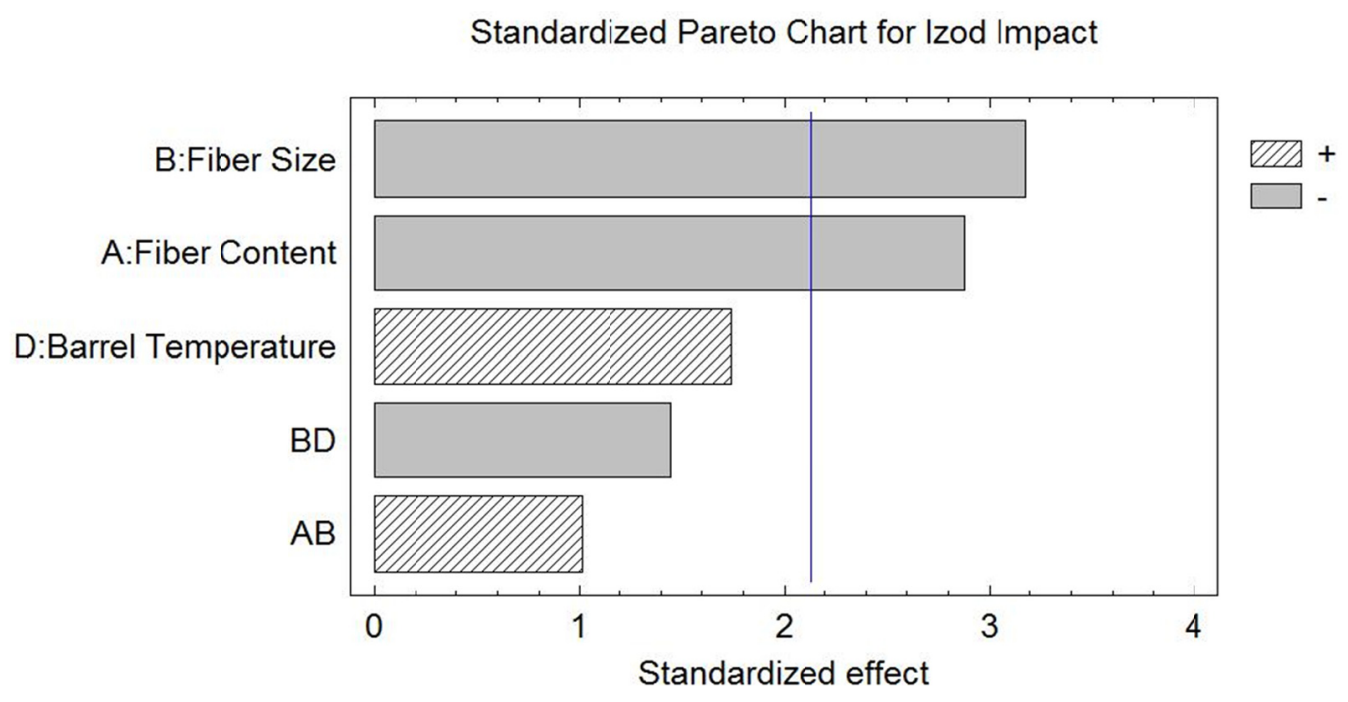

Figure 9. Standardized Pareto Chart for Izod impact 


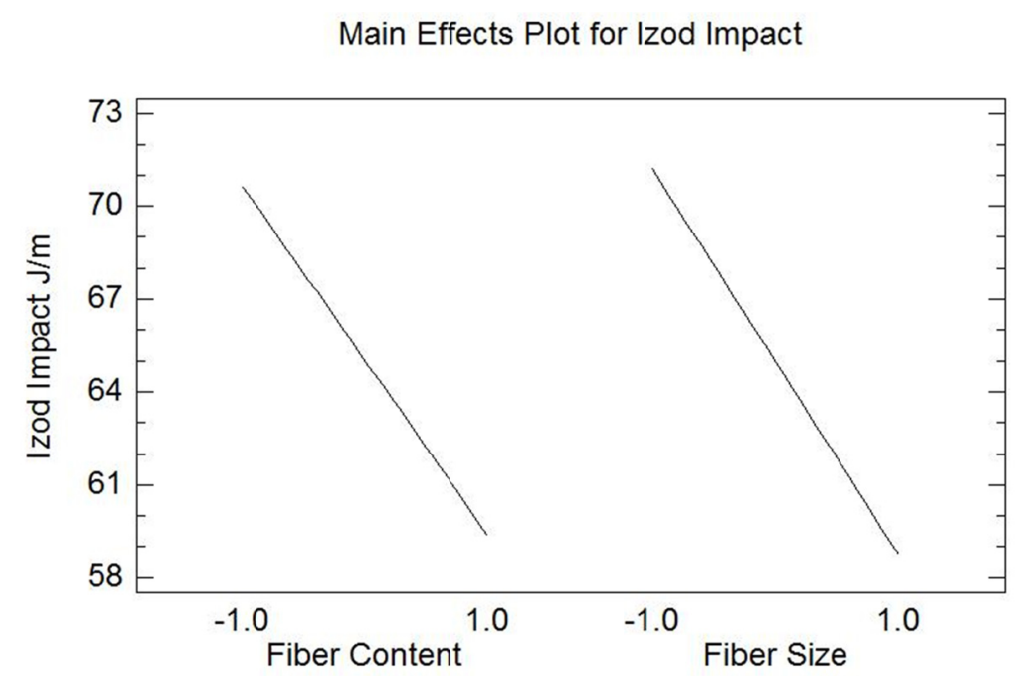

Figure 10. Izod impact resistance-Main effects

In addition to the results already described, the design analysis also showed that neither screw speed nor barrel temperatures presented influence on any property investigated in this work. This observation suggests that shear history did not produce fiber degradation during extrusion process. The same conclusion can be observed for the temperature gradient. As shown at Table 3, the degradation temperature range for LC-fiber is $352-372^{\circ} \mathrm{C}$, which is higher than the values used in the design experiments.

Model and respective estimative response surface for the TS, MOE, FS and Izod impact resistance are presented, respectively, in Table 5 (Equations 1-4) and Figures 11-14.

Table 5. Models and Standard error estimate for TS, MOE, FS and Izod impact resistance

\begin{tabular}{|c|c|c|c|}
\hline \multicolumn{2}{|l|}{ Model } & $\begin{array}{l}\text { Standard error } \\
\text { estimate }\end{array}$ & Eqs \\
\hline \multicolumn{2}{|c|}{$\begin{array}{c}\text { TS }(\mathrm{MPa})=17.53+0.171 * \mathrm{~A}+0.262 * \mathrm{C}-0.224 * \mathrm{D}-0.428 * \mathrm{~A} * \mathrm{~B}+0.278 * \mathrm{~A} * \mathrm{D} \\
+0.192 * \mathrm{~B} * \mathrm{D}+0.257 * \mathrm{C} * \mathrm{D}\end{array}$} & $0.64 \mathrm{MPa}$ & (1) \\
\hline \multicolumn{2}{|c|}{$\begin{array}{c}\operatorname{MOE}(\mathrm{MPa})=1097.57+328.19 * \mathrm{~A}+18.563 * \mathrm{~B}-18.688 * \mathrm{~A} * \mathrm{~B}+34.688 * \mathrm{~A} * \mathrm{D}- \\
33.688 * \mathrm{~B} * \mathrm{C}\end{array}$} & $64 \mathrm{MPa}$ & (2) \\
\hline \multicolumn{2}{|c|}{$\begin{array}{c}\mathrm{FS}(\mathrm{MPa})=31,824+2.5813 * \mathrm{~A}+0.18125^{*} \mathrm{~B}-0.35625 * \mathrm{~A} * \mathrm{~B}-0.10625 * \mathrm{~A} * \mathrm{C}- \\
0.10625 * \mathrm{~B} * \mathrm{D}\end{array}$} & $0.4 \mathrm{MPa}$ & (3) \\
\hline \multicolumn{2}{|c|}{$\begin{array}{c}\text { Izod impact }(\mathrm{J} / \mathrm{m})=64.976-5.6419 * \mathrm{~A}-6.2344 * \mathrm{~B}+3.4181 * \mathrm{D}+1.9806 * \mathrm{~A} * \mathrm{~B}- \\
2.8469 * \mathrm{~B} * \mathrm{D}\end{array}$} & $7.9 \mathrm{~J} / \mathrm{m}$ & (4) \\
\hline \multicolumn{4}{|c|}{ Where: } \\
\hline \multicolumn{4}{|c|}{$\begin{array}{l}\text { A (LC-fiber content })=-2+0.1 x ; \quad 10 \leq x \leq 30 \% \\
\text { B (LC-fiber size })=1.6-4.1 y ; 0.63 \geq y \geq 0.15 \mathrm{~mm}\end{array}$} \\
\hline \multicolumn{4}{|c|}{$\mathrm{C}($ Screw speed $)=-5+0.1333 z ; \quad 300 \leq y \leq 450 \mathrm{RPM}$} \\
\hline $\mathrm{D}($ Barrel temperature zone $)=-8+0.05 w$ & $140 \leq w \leq 180^{\circ} \mathrm{C}($ zone 2 to 5$)$ & & \\
\hline $\mathrm{D}($ Barrel temperature zone $)=-9+0.05 w$ & $160 \leq w \leq 200^{\circ} \mathrm{C}$ (zone 6 to 9$)$ & & \\
\hline $\mathrm{D}($ Barrel temperature zone $)=-10+0.05 w$ & $180 \leq w \leq 220^{\circ} \mathrm{C}(\mathrm{Die})$ & & \\
\hline
\end{tabular}




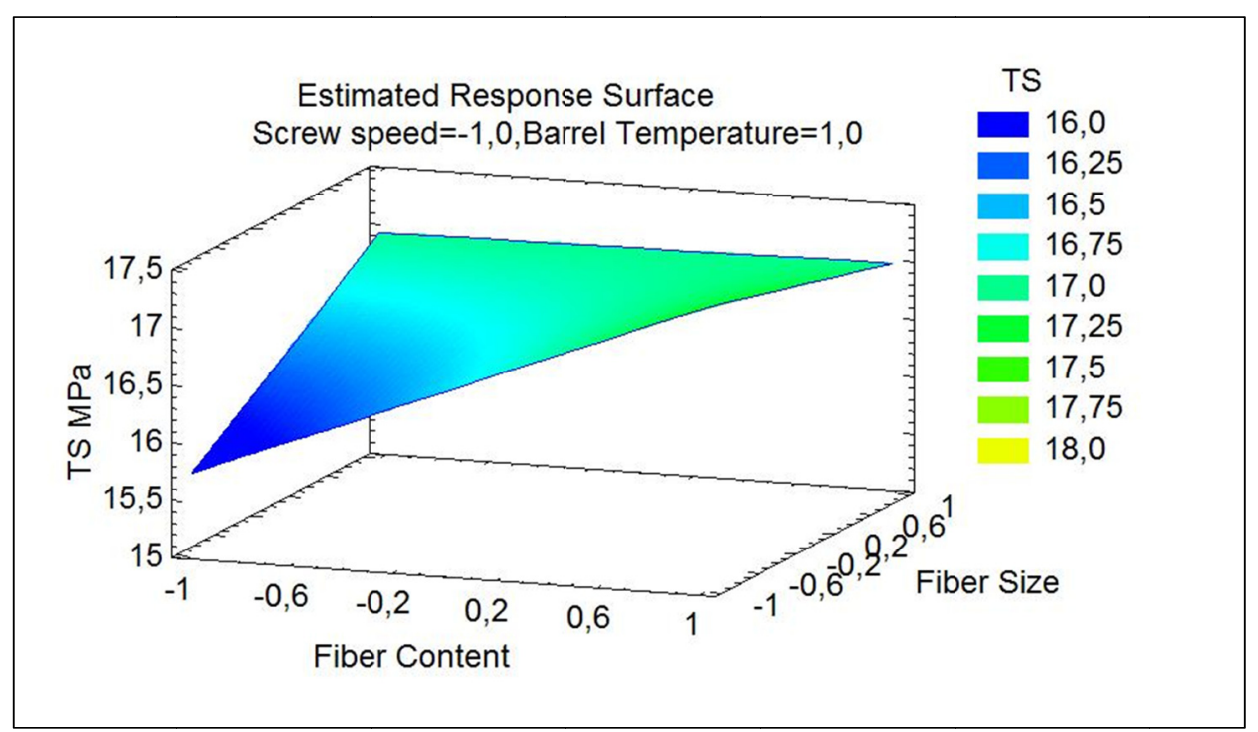

Figure11. Estimative response surface for TS at screw speed $=-1$ and Barrel temperature zone $=1$

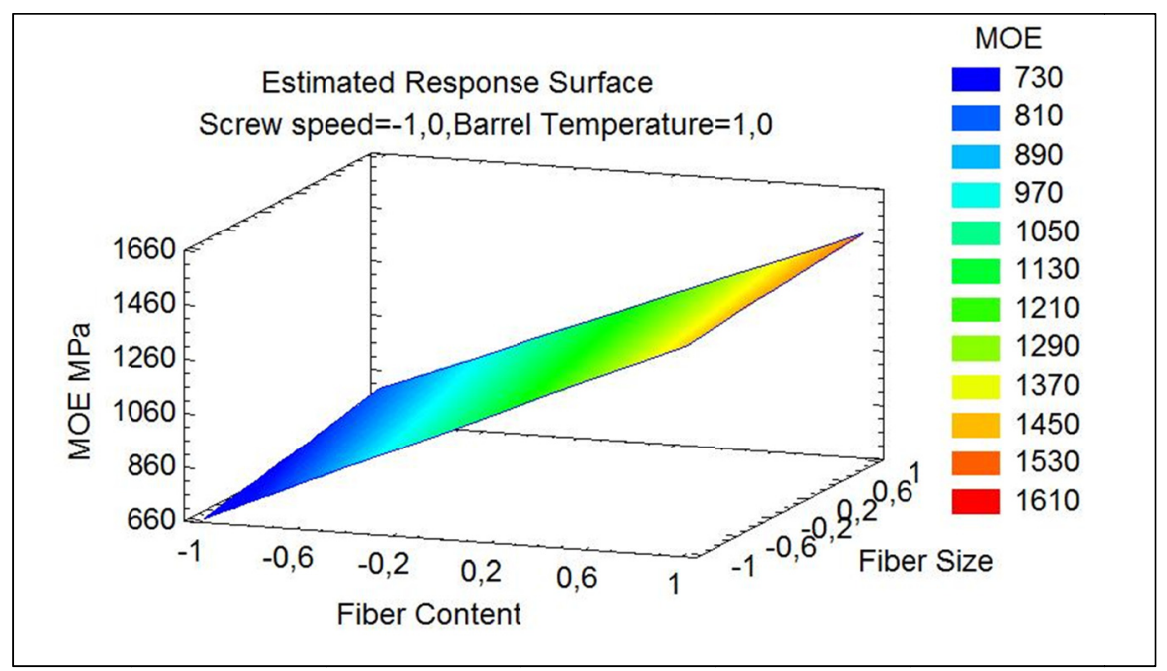

Figure 12. Estimative response surface for $\mathrm{MOE}$ at screw speed $=-1$ and Barrel temperature zone $=1$

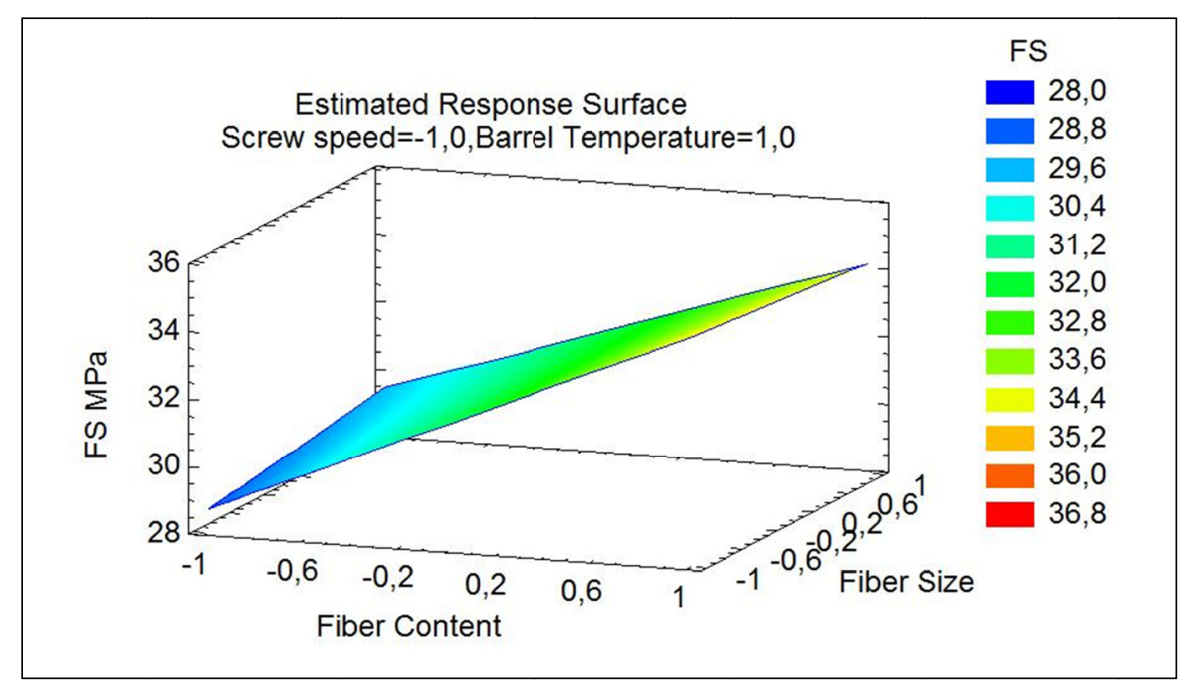

Figure 13. Estimative response surface for FS at screw speed $=-1$ and Barrel temperature zone $=1$ 


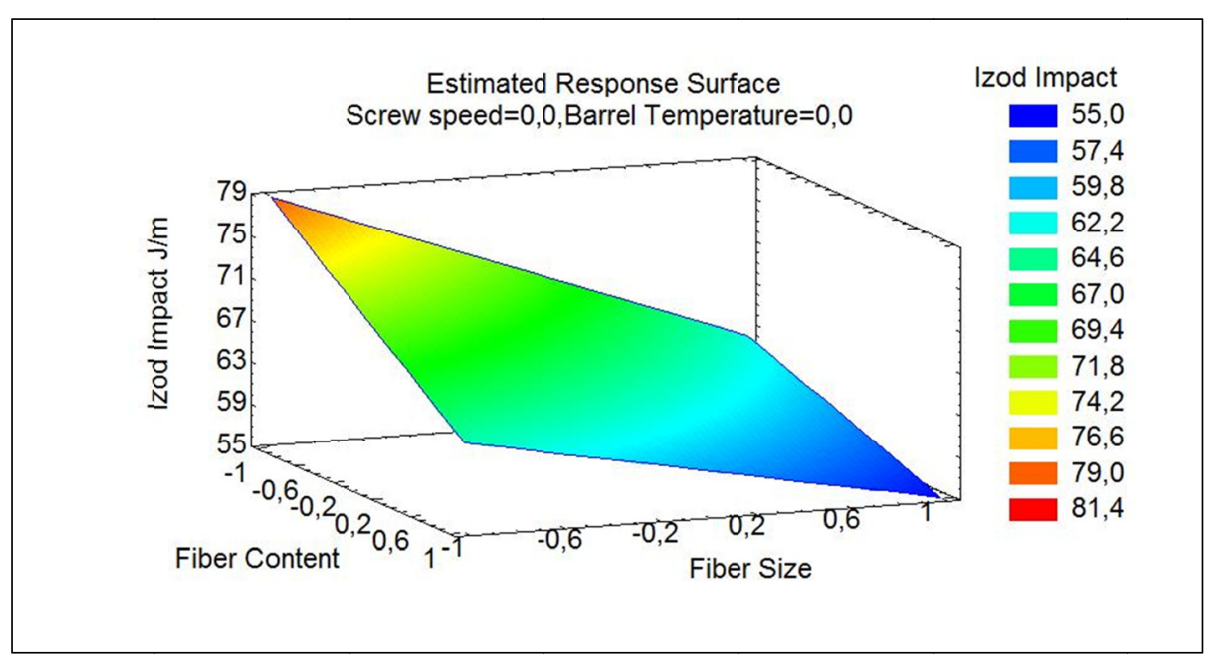

Figure 14. Estimative response surface for Izod impact resistance at screw speed $=0$ and Barrel temperature zone $=0$

Furthermore, in order to verify the suitability of each model, an additional experimental run was carried out using the following factors: LC-fiber content $=-1$; LC-fiber size $=0$; screw speed $=-1$ and barrel temperature zone $=1$. The comparison between the actual values of each mechanical property of the additional experimental run with the predicted value obtained from the respective model is shown in Table 6 . This comparison shows that all models provide reasonably accurate prediction as far as the investigated mechanical properties of LC-fiber/HDPE composites are concerned.

Table 6. Observed and Predicted values comparison of additional experimental run

\begin{tabular}{lccc}
\hline \multirow{2}{*}{ Property } & Observed & \multicolumn{2}{c}{ Predicted values } \\
\cline { 3 - 4 } & Value & Fitted value & Mean limits \\
TS (MPa) & 17.8 & 17.9 & $17.0-18.7$ \\
MOE (MPa) & 819 & 804 & $749-859$ \\
FS (MPa) & 29.0 & 29.1 & $28.8-29.5$ \\
Izod Impact resistance $(\mathrm{J} / \mathrm{m})$ & 72,1 & 67.2 & $60.2-74.1$ \\
\hline
\end{tabular}

\section{Conclusions}

This work showed that fiber content strongly affected sponge-gourd agrofiber residue-HDPE composites properties, precisely MOE, FS and Izod Impact resistance. In addition, the analysis of the experimental design showed that fiber size has also influenced on Izod Impact resistance. On the other hand, screw speed and temperature of barrel zones have not presented any influence on the properties investigated, indicating that fiber have not suffered mechanical and thermal degradations. This study also demonstrated that as all models provided accurate prediction, they could be used to investigate and optimize mechanical properties. Finally, the results of this study also suggest that sponge-gourd agrofiber residue is a potential lignocellulosic fiber to be used in HDPE composite, although no additive was used in order to improve the interaction between polymer and fiber.

\section{Acknowledgements}

Authors thank to Banco Nacional de Desenvolvimento Econômico e Social (BNDES), Fundação de Amparo à Pesquisa do Estado do Rio de Janeiro (FAPERJ), Conselho Nacional de Desenvolvimento Científico e Tecnológico (CNPq), Coordenação de Aperfeiçoamento de Pessoal de Nivel Superior (CAPES) and Financiadora de Estudos e Projetos (FINEP) for the financial and technical support. 


\section{References}

Altınısik, A., Gür, E., \& Seki, Y. (2010). A natural sorbent, Luffa cylindrica for the removal of a model basic dye. Journal of Hazardous Materials, 179(1), 658-664. http://dx.doi.org/10.1016/j.jhazmat.2010.03.053

ASTM D1348-94. (2003). Standard Test Methods for Moisture in Cellulose. ASTM-Annual Book of ASTM Standars, Philadelphia, Plastics.

ASTM D1238-10. (2007). Standard Test Method for Melt Flow Rates of Thermoplastics by Extrusion Plastometer. ASTM-Annual Book of ASTM Standars, Philadelphia, Plastics, 08.01.

ASTM D638 -03. (2007). Standart Test Methods for Tensile properties of plastics. ASTM-Annual Book of ASTM Standars, Philadelphia, Plastics, 08.01.

ASTM D790-03. (2007). Standart Test Methods for Flexural properties of Unreinforced and Reinforced Plastics and reinforced plastics and electrical insulating materials. ASTM-Annual Book of ASTM Standars, Philadelphia, Plastics, 08.01, pp. 150-160.

ASTM D256-06a. (2007). Standart Test Methods for Determining the Izod Pendulum Impact Resistence of plastics and electrical insulating materials. ASTM-Annual Book of ASTM Standars, Philadelphia, Plastics, 08.01, pp. 1-20.

Boynard, C. A., Monteiro, S. N., \& d'Almeida, J. R. M. (2003). Aspects of alkali treatment of Sponge Gourd (Luffa cylindrica) Fibers on the Flexural Properties of Polyester Matrix Composites. Journal Applied Polymer Science, 87, 1927-1932. http://dx.doi.org/10.1002/app.11522

Demir, H., Atikler, U., Balköse, D., \& Tihminlioglu, F. (2006). The effect of fiber surface treatments on the tensile and water sorption properties of polypropylene-luffa fiber composites. Composites Part A: Applied Sciense and Manufacturing, 37, 447-456. http://dx.doi.org/10.1016/j.compositesa.2005.05.036

Finkler, M., Scapini, P., Freire, E., Zattera, A. J., \& Zeni. M. (2005). Compósitos de HDPE com resíduos de fibras têxteis. Parte I: Caracterização mecânica. Polímeros: Ciência e Tecnologia, 15(3), 171-175.

Herrera-Franco, P. J., \& Valadez-Gonzales, A. (2005). A study of the mechanical properties of short natural-fiber reinforced composites. Composites: Part B:engineering, 36, 597-608. http://dx.doi.org/10.1016/j.compositesb.2005.04.001

Lei, Y., Wu, Q., Yao, F., \& Xu, Y. (2007). Preparation and properties of recycled HDPE/natural fiber composites. Composites Part A: Applied Science and Manufacturing, 38(7), 1664-1674. $\mathrm{http}: / / \mathrm{dx}$.doi.org/10.1016/j.compositesa.2007.02.001

Liu, H., Wu, Q., \& Zhang, Q. (2009). Preparation and properties of banana fiber-reinforced composites based on high density polyethylene (HDPE)/Nylon-6 blends. Bioresource Technology, 100(23), 6088-6097. http://dx.doi.org/10.1016/j.biortech.2009.05.076

Mishra, S., Mohanty, A. K., Drzal, L. T., Misra, M., \& Hinrichsen, G. (2004). A review on pineapple leaf fibers. sisal fibers and their biocomposites. Macromolecular Materials Engineering, 289, 955-974. http://dx.doi.org/10.1002/mame.200400132

Mohanty, S., \& Nayak, S. K. (2010). Short bamboo fiber-reinforced HDPE Composites: Influence of fiber modification on strength of the composite. Journal of Reinforced Plastics and Composites, 29, 2199-2210. http://dx.doi.org/10.1177/0731684409345618

Mulinari, D. R., Voorwald, H. J. C., Cioffi, M. O. H., da Silva, M. L.C. P., da Cruz, T. G., \& Saron, C. (2009). Sugarcane bagasse cellulose/HDPE composites obtained by extrusion. Composites Science Technology, 69(2), 214-219. http://dx.doi.org/10.1016/j.compscitech.2008.10.006

Standart Method T211 om-93-Tappi Test Methods. (1993). TAPPI-Technical Association of Pulp and Paper Industry.

Standart Method T212 om-98-Tappi Test Methods. (1998). TAPPI-Technical Association of Pulp and Paper Industry. 